\title{
THE IMPACT OF MILITARY R\&D ON THE INNOVATIVE DEVELOPMENT OF THE CIVILIAN SECTOR
}

\author{
Harutyunyan Gayane E. \\ $\mathrm{PhD}$ (Economics), Assistant Professor, Senior Research Associate, \\ M. Kotanyan Institute of Economics, National Academy \\ of Sciences of the Republic of Armenia. \\ Address: 15 Grigor Lusavorchi Str., 0015, Yerevan, Republic of Armenia \\ E-mail: harutyunyan.gayanne@mail.ru
}

\begin{abstract}
The main route of economic development on an innovative basis implies the efficient implementation of scientific research and development activities (R\&D) in a country. However, if economists generally agree that $\mathrm{R} \& \mathrm{D}$ expenses contribute to the technological development of the economy and improve the sectorial structure of industry in favor of highly technological, value adding industries, then the contradictions between scientific viewpoints in debates on the impact of military R\&D expenses are of a more acute character. Even in cases where empirical researches reveal the positive interdependence between military $R \& D$ expenses and the most important indicators of economic development, the issues regarding their benefit to broad layers of society always remain disputable. The article summarizes analyses of the impact of military R\&D on the economy conducted at different times, and coordinates the conclusions drawn. The main directions of impact of military R\&D on the economy are presented: security effect, aggregate demand growth effect, aggregate supply growth effect, positive spillover effect, negative spillover effect, and crowding-out effect. In addition, the dynamics of military R\&D in Armenia have been studied and certain judgments evaluating their peculiarities are presented.
\end{abstract}

Keywords: military R\&D; economic growth; security effect; spillover effect; crowding-out effect; external costs.

Citation: Harutyunyan, G.E. (2017). The Impact of Military R\&D on the Innovative Development of the Civilian Sector. Public Administration Issues, Special Issue (electronic edition), pp. 27-37 (in English); doi: 10.17323/1999-5431-2017-0-5-27-37.

\section{Introduction}

The main route of economic development on an innovative basis implies the efficient implementation of scientific research and development activities (R\&D) in a country, which in its turn depends on the amount and reasonableness of fi- 
nancing allocated to these activities; large R\&D expenses can be afforded primarily by developed economies. A closed chain is created, which has led to a situation in the global economy where at the initial stages of technological lifecycles the main manufacturers are developed countries. However, the experience of certain countries (Israel (Broude et al., 2013), South Korea (Weitz, 2013), and Singapore (Kuah and Bernard, 2004)) indicates that the efficiency of R\&D expenses can enable countries with small open economies to overcome the technological gap with developed economies and identify new backbones for economic development.

Many countries incur military R\&D expenses aimed at increasing their military and defense capabilities through technological improvement. Of course, the initial motivation for creating such expenses is not the economic development of the country or the receipt of economic benefits. However, it can lead to both significant positive spillover effects as a result of the application of scientific achievements gained in civilian industries, and also to unforeseen negative spillover effects, most often in the form of external costs, which can become a reason for structural disproportion in the economy, causing formidable problems. There are certain exceptions, but one example of how the negative influence of military R\&D expenses on the economy can serve the underproduction of consumer goods was the result of the militarization of the USSR economy, which led to the gradual aggravation of social problems and finally the collapse of the USSR.

Under the conditions of effective development regularities of the market economy, where the confidentiality level of R\&D activities carried out in the military sphere has been significantly reduced, the state monopoly in the production of military-industrial products has been partially abolished, the role of private enterprises in the global arms market has become more significant, technology transfer pipelines between different sectors have become more transparent and unobstructed, and the probability of positive spillover effects from government spending allocated to military R\&D has been considerably increased. Also, the existence of a clearly developed dual purpose production development strategy can allow for minimizing the probability of unforeseen negative effects. Therefore, importance is attached to assessment of the impact of military R\&D expenses on the economy, not only in terms of the identification of spillover effects but also, in the context of their analysis, as an essential factor of the innovative development of the country.

The study of military R\&D expenses impact on the innovative development of the economy and particularly on the civilian sector requires analyses in the following areas:

- the study of possible changes in the general productive capacity of the economy as a result of development and the introduction of new technologies,

- the impact of military innovations on the development of civilian industries;

- the assessment of possible differences in the productivity rate conditioned by different funding sources (own, attracted and state);

- the impact of the general conditions of the economic development and the existence of an industrial base on the efficiency of military R\&D expenses;

- the comparative assessment of the efficiency of military and civilian R\&D financed by the state. 
The main objective of the article is to coordinate the existing empirical and theoretical researches on the impact of military R\&D on the economy, aimed at identifying certain regular occurrences of this impact, as well as to present the dynamics of military R\&D in Armenia and the peculiarities of their influence on the economy.

\section{Theoretical and empirical substantiations of the impact of military R\&D}

The issues related to the impact of scientific and technical progress on the economy and to the management of expenses incurred on R\&D became the subject of active discussions in economic research in the middle of the last century, when Solow in his article "A Contribution to the Theory of Economic Growth" suggested viewing knowledge as an independent factor affecting economic growth (Solow, 1956), and in the article "Technical Change and the Aggregate Production Function" published in 1957, he had already presented certain instruments of macroeconomic analysis that treat technological progress as the most important factor of economic growth (Solow, 1957). However, if economists generally agree that R\&D expenses contribute to the technological development of the economy, improve the sectorial structure of industry in favor of highly technological, value adding industries, and the main contradictions arise only during analysis of the results of empirical researches conducted for the establishment of these realities, the contradictions between scientific viewpoints in the debates on the impact of military R\&D expenses are of more acute character. Even in cases where the empirical researches reveal a positive interdependence between military R\&D expenses and the most important indicators of economic development, the issues of their benefit to broad layers of society always remain disputable. However, the fact is that during the second half of the 20th century, as a result of research and development activities carried out for military purposes, revolutionary technological innovations such as satellite communication, jet engines, semi-conductors, nuclear energy, the space industry, the Internet, etc. have been achieved (Naughton, 2016).

With respect to this issue, the main argument-alternative in scientific debates is that innovations and greater results in economic development based thereon can be achieved if the R\&D expenses prevail in civilian industry and are made on the initiative of private entrepreneurs pursuing commercial interests. The researches that evidence the truthfulness of this viewpoint are few in number in economic literature due to the limited amount of data on military R\&D published by various countries, as well as by the imperfections in the methodological and conceptual approaches to the assessment of spillover effects. One such research (Leonard, 1971) has revealed that in the USA in the 1960s the activity shown in the research sphere (measured by R\&D expenses incurred by the companies) had a positive significant correlation with sales volume, assets, net income and other indicators of 16 industrial enterprises, however, when the state $R \& D$ expenses were also included, the correlation failed to be significant. After excluding from the research those industrial sectors consuming 5/6 of the state funds, namely, the aircraft industry, rocket engineering and the production of electric appliances, the significant correlation was recovered. This has allowed us to conclude that industrial growth 
is slowed down as a result of the reallocation of $R \& D$ expenses incurred for defense or space industry purposes. Another research, conducted on four industrial sectors in Canada (aerospace, shipbuilding, electronics and chemical industries) and based on 1961-1985 data (Poole and Bernard, 1992) drew the conclusion that military innovations had a significant negative impact on the growth of total factor productivity, especially in the aerospace and electronics industries, and that this negative impact had a weaker impression on the shipbuilding and chemical sectors. Later, during the study on the impact of R\&D activities on productivity growth conducted for 16 OECD countries, the authors (Guellec and Pottelsberghe, 2001) identified that state funding in general had a negative effect on $R \& D$ activities carried out in the private sector, and only military-related expenses had a significant negative impact on multi-factor productivity levels, whereas the state funding of civilian R\&D had a positive impact on innovations and business revival in the private sector.

Similarly, Moretti et al. (2016) used a unique dataset that contains detailed information on defense-related government funded $\mathrm{R} \& \mathrm{D}$, non-defense related government funded $R \& D$, private $R \& D$, output, employment and salaries in 26 industries in every OECD country over a 23 year period, to look at how government funding $R \& D$ impacted on privately performed $R \& D$ and its ultimate effect on productivity growth. In this study, defense R\&D expenditures are used as an instrumental variable. They found strong evidence of crowding in: increases in government funded $R \& D$ generated by increases in defense $R \& D$ translate into significant increases in privately funded R\&D expenditures, with the most reliable estimates of the long run elasticity between 0.2 and 0.5 . On average, $\$ 1$ of additional public funds for R\&D translates into $\$ 2.4$ to $\$ 5.9$ of extra R\&D funded by the private sector. Defense related R\&D is responsible for an important portion of private R\&D investment in some industries. For example, in the US "aerospace and other transport equipment" industry, defense related R\&D amounted to $\$ 36.9$ bn in 2003 (2016 prices). The study also indicates that cross-country differences in defense R\&D might play an important role in determining cross-country differences in overall private sector $\mathrm{R} \& \mathrm{D}$ investment. For example, if Germany increased its defense R\&D as a fraction of GDP to the level of the US, privately funded R\&D would increase by $44 \%$.

As for the "crowding-out" effect of military R\&D in civilian industries arising as a result of financing military $\mathrm{R} \& \mathrm{D}$, the empirical researches (particularly, Buck et al., (1993)) overall have not managed to identify any clear long-term relationship between military and civilian R\&D, therefore they are unable to prove the existence of any crowding-out effect. However, certain researchers (e.g. Hartley, (2006)) believe that in the military sphere the R\&D activities have obvious alternative expenses, since often limited high-quality scientific human resources and assets are used on monopolistic conditions that otherwise could be used for civilian research and development activities. In contrast, many studies exist (for example in the USA, Chakrabarti et al., (1993), and Israel's example, Peled, (2001)), which prove that military R\&D contributes to the growth of production output in civilian industries, and therefore, also supports economic growth conditioned by technological changes, the basis of which are the licenses for the use of military R\&D results. 
Some studies have analyzed in more detail the considered relationship from the point of view of the differences between types of countries. Fredericksen and Looney $(1985,1989)$ found that military spending had a negative influence on growth for "resource constrained" developing countries, but positive for "resource unconstrained" and that this impact is a more positive for countries that have an indigenous arms industry. The link between the arms trade, military spending and growth is also examined in the study by Yakovlev (2007), which revealed a negative impact of military expenditure on growth across a sample of developed and developing countries, but this negative impact reduced the more the country was a net exporter of arms.

Morales-Ramos considers the existence of such contradictory conclusions natural (Morales-Ramos, 2002), being of the opinion that the efficiency of military $\mathrm{R} \& \mathrm{D}$ and the demonstration of their impact vary from country to country, which considerably complicates the identification of general regularities. The analysis conducted for Great Britain allowed him to conclude that the indirect crowding-out effects, in substance, did not exceed the direct positive spillover effects, so it could be assumed that the net impact of military R\&D expenses on economic growth is positive.

The influence of military R\&D expenses on the economy definitely cannot be limited to just crowding-out or side effects, it is quite important to take into account such factors as a high level of national security, which increases the utility of households (security effect) and the possibility of the development of generalpurpose technologies by means of military $\mathrm{R} \& \mathrm{D}$, which in economic literature is known as a spin-off effect. In this context, it can be stated that the impact of R\&D on economic growth implies substantial uncertainties. Particularly, if the reduction in expenses for military R\&D occurs when their starting level is considerably high, it would have a positive impact on economic growth, whereas in the case of a low starting level in military R\&D expenses, the impact would be negative. In fact, such a level of military R\&D expenses exists, which maximizes economic growth due to the positive spillover effect and the spin-off effect, and at the same time, there is such a level of military R\&D expenses that maximizes the welfare function of households owing to the security effect. The difference between these two critical levels is almost always conditional upon the security effect: if it is low, the level of R\&D maximizing the welfare of households will be lower than the level of R\&D maximizing economic growth (Chu and Lai, 2009).

Investigation of the causal relationship between military spending and social welfare expenditures is also very important because there is a trade-off between military expenditures and other major government spending. An empirical study (Lin et al., 2015) based on the panel data of 29 OECD countries from 1988 to 2005, revealed a positive trade-off between military spending and two types of social welfare expenditures (i.e. education and health spending). The authors found that the reasons may be that OECD countries are more supportive of social welfare programs; therefore, when military spending is increased (e.g. military personnel and conscripts), the government may raise health and education spending as well.

A particularly interesting study is the comparatively new Schmid (2017) analysis using negative binominal and zero-inflated negative binominal regression 
models for assessing the impact of the rate at which defense-funded knowledge diffuses into subsequent innovations on the overall innovation system. The most remarkable finding of study is that there is no statistically significant difference in the rates at which military and civilian technologies diffuse. This finding contradicts the prevailing scientific view that the modern defense sector features restrict the diffusion of technologies developed therein.

Summarizing the results of the existing researches and conclusions drawn thereon, the following main directions of impact of military R\&D on the innovative development of the economy shall be distinguished:

- Security effect, which on the one hand ensures the existence of a secure and reliable environment for economic activity in the country, thus contributing to the growth of domestic and foreign investments and business revival, and on the other hand, implies the growth of the public utility function, since one of the key public benefits included therein, namely national security and defense ability, is improved significantly in quality owing to technological progress.

- Aggregate demand growth effect, the impact mechanism of which is indirectly linked to a change in the public welfare function: when it grows, the consumer expenses of households are increased.

- Aggregate supply growth effect, which is possible to achieve due to productivity growth and the reduction of production costs in the economy as a result of technological progress.

- Positive spillover effect, when military technologies are transferred to other industry sectors and contribute to general technological progress in the economy. Three options demonstrating positive externalities can be distinguished:

- Spin-off effect, when technologies developed as a result of military R\&D, having met as a priority the military and defense requirements, are later transferred (through the sale of patents and licenses) to civilian industries;

- Spin-in effect, when the country's R\&D expenses are directed mainly to the development of civilian technologies by private companies, however these companies also fulfil state orders for military and defense needs or on their own initiative (although based on a license issued by the government) produce military products, the realization of which is arranged on commercial terms;

- Spin-on effect, in cases whereby military R\&D make it possible to also develop general-purpose technologies, so that enterprises producing military products are always able to switch to the production of civilian products (conversion).

- Crowding-out effect, the impact of which is negative due to the attraction of high-quality human resources and assets from civilian industries, resulting in worsening (or in losing the possibility to improve) productivity in those industries and other economic indicators.

- Negative spillover effect, which is demonstrated by excess resource expenses since under the conditions of state-guaranteed sales of manufactured products and a considerable amount of state funding, the main burden is carried by society, which does not always act as a consumer of the products produced by the $\mathrm{R} \& \mathrm{D}$ activities. This issue is more common in those countries which, 
being in no danger of taking part themselves in a military emergency, carry out significant R\&D for the production of advanced weapons, which are mainly exported.

It is obvious that analysis of the impact of military $\mathrm{R} \& \mathrm{D}$ in each of the directions stated above is impossible, purely due to the fact that a number of key factors exist that are not subject to quantitative measurement. Such factors include, for example, society's perception of defense or the moral and psychological position of society with respect to the production of weapons, which can often be decisive in the decision-making process of economic entities at the micro level. In addition, it is not always possible to distinguish between the boundaries of these effects and the possibilities of their multiplicative impact. Therefore, the analytical models always assume a considerable degree of scientific abstraction and consequently imply contradictions in their conclusions.

\section{Dynamics of military R\&D expenses in Armenia and peculiarities of their impact on the economy}

As a rule, the development of mechanisms for the growth of the military industry and more effective use of government spending allocated to defense is typical, especially of those countries which are in a certain critical situation (war, frozen conflict, military embargo, blockade, etc.). Such examples are numerous: Israel (Schein, 2017), Turkey (Bağc1 \& Kurç, 2016), Brazil, and Egypt (Brauer, 2002) on which an arms import embargo was imposed for various reasons and which began to develop domestic arms production. Armenia is beyond the scope of this pattern. Being in a frozen conflict zone and also experiencing a bilateral blockade by neighboring Azerbaijan and Turkey, Armenia, in fact, has not undertaken any significant measures for the development of its military industry forced by national security requirements. In particular, necessary attention has not been focused on military R\&D and its potential benefits. First, it should be stated that a breakdown of the amount of financing for research and development activities within the total defense expenses, under the laws on the RA state budget, have been available since 2008 (relevant statistical data is presented in Table).

Table

\section{Dynamics of financing of R\&D in the military sphere in 2008-2016, in bln. AMD}

\begin{tabular}{|l|c|c|c|c|c|c|c|c|c|}
\hline \multicolumn{1}{|c|}{ Year } & $\mathbf{2 0 0 8}$ & $\mathbf{2 0 0 9}$ & $\mathbf{2 0 1 0}$ & $\mathbf{2 0 1 1}$ & $\mathbf{2 0 1 2}$ & $\mathbf{2 0 1 3}$ & $\mathbf{2 0 1 4}$ & $\mathbf{2 0 1 5}$ & $\mathbf{2 0 1 6}$ \\
\hline $\begin{array}{l}\text { Total defense expenses } \\
\text { Research and development } \\
\text { activities in the military sphere }\end{array}$ & 0.8 & 1.0 & 1.0 & 1.1 & 1.2 & 1.4 & 1.5 & 1.6 & 1.6 \\
\hline Share in total defense expenses, \% & 0.6 & 0.6 & 0.7 & 0.8 & 0.8 & 0.7 & 0.8 & 0.8 & 0.8 \\
\hline
\end{tabular}

Source: Laws on the RA state budget, 2008-2016 http://www.parliament.am/legislation.php?sel=alpha\&ltype= 3\&lang=arm 
Prior to that, funds allocated for defense were presented in two subgroups in the state budget - "military needs" and "other defense needs". Given the fact that in 1995-2007 the expenses of the second subgroup amounted to 5\%-7\% of total defense expenses, and following the dynamics of the financing of R\&D in subsequent years, which fluctuated within the range of $0.6 \%-0.8 \%$ of the total defense expenses, we can insist on the incompatibility of the 1995-2016 data. At the same time, the lack of quarterly or semi-annual data in the available statistical information makes the results of econometric statistical researches unreliable. Besides, in cases whereby we decide to rely on the research insisting that military R\&D expenses that are low by an absolute indicator have an almost zero impact on the overall development of economy (Pieroni, 2009), the examination of the realities of the impact of military R\&D expenses on the economy of Armenia is significantly complicated. Therefore, we have tried to build up our estimates primarily based on logical judgments.

Thus, any negative impact of military R\&D on the Armenian economy can be excluded due to the existence of significant unrealized production capabilities and free manufacturing resources in the economy. Under such conditions, there is no sufficiently large real sector in order to demonstrate any crowding-out effect. There are few civilian research activities carried out in the country (the state funding of which makes up only about $0.25 \%$ of GDP) with a rather low level of commercialization of the results. Therefore, military R\&D, the prioritized necessity of which is dictated by the urgent solution of the security issues of the country, can serve as a successful precondition for technological progress in the country, by including other technology-based industry sectors (chemicals, machinery engineering, information technology, etc.) in its technological processes.

At the same time, ensuring the possible security effect is of high importance for Armenia in current geopolitical conditions. Based on various estimates, as a result of the economic blockade, Armenia loses 30\%-40\% of potential direct foreign investment, and what is more problematic, local investors also avoid investing in the real sector, often preferring to invest in other countries (Avetisyan et al., 2015). Sure enough, these circumstances are to some extent conditioned by the security issues of the country.

Perhaps the only direction of any negative impact of military R\&D expenses on the economy of Armenia is the growth of the additional tax burden for society, since ultimately the state budget financing is provided at the expense of the taxpayers. A heavier tax burden leads to a reduced net income for individuals and private corporations, leaving less money for saving and for private investment. Regardless of the financing measure, increased defense spending is likely to limit the amount of funds available for private investment, which is critical, particularly in developing countries due to their shortage of capital resources (Uk Heo, Min Ye, 2016). Although the situation is quite different if the country has its indigenous defense industry. Thus, by investing in the defense industry, such as the purchase of military equipment or R\&D expenditure, the government effectively uses taxpayers' money, since a significant part of this quickly returns to the state budget as taxes. Studies have shown that of the 100 currency units allocated for defense, 43 units are returned to the budget by tax payments (Lavrinov, 2007). 
However, if we take into account all the possible direct and indirect benefits of efficient R\&D expenses in the long-term, for example, the domestic production of arms and ammunition at the initial stage of their technological lifecycle, and opportunities for the manufacture of innovative civilian products owing to technology transfer, such use of state funding appears more acceptable than the expenses incurred for the import of arms which are at the final stage of their technological lifecycle.

\section{Conclusions}

The impact on the economy of R\&D carried out for defense and military purposes is multi-vector, and these impact vectors often imply adverse effects on the overall economy and its individual phenomena, and in some cases these vectors play the role of accelerator to each other. This significantly complicates the task of assessing the impact on the economy and leads to contradictory conclusions since analytical models usually involve a considerable degree of scientific abstraction. However, researches conducted in this area have allowed for distinguishing some regularities in interconnection between military R\&D and economic growth. These are:

- security effect;

- $\quad$ aggregate demand growth effect;

- $\quad$ aggregate supply growth effect;

- $\quad$ positive spillover effect (including spin-off, spin-in and spin-on effects);

- crowding-out effect,

- negative spillover effect.

The peculiarities of demonstration of the above stated effects in the economy of Armenia are linked to significant complications due to the limited amount of information available and its incompatibility, as well as considerably lower absolute indicators of military R\&D expenses, which pre-suppose that these expenses could not have any material impact on economic indicators. However, based on certain estimative judgments we have concluded that under the present conditions of economic development in Armenia the possibility of any negative impact of military R\&D can be excluded, except for perhaps the additional tax burden borne by society. This burden, however, appears to be much lower if we consider that as a potential result of these activities, locally produced arms and ammunition can replace the import of arms which are at the final stage of their technological lifecycle. 


\section{REFERENCES}

1. Chu, A.C. \& Ching-Chong Lai (2012). Defense R\&D: Eects on Economic Growth and Social Welfare. Public Economic Theory, vol. 14, no 3, pp. 473-492. Available at: http://eml.berkeley.edu/ moretti/military.pdf (accessed: 10 July, 2017).

2. Avetisyan, S. et al. (2015). Sp'yowr'qi nerdrowmnery' Hayastani tntesowt'yan mej zargacman herankarnery' [Diaspora's Investments in Armenian Economy: Development Perspectives]. Yerevan: AMBERD (in Armenian).

3. Brauer, J. (2002). The Arms Industry in Developing Nations: History and Post-Cold War Assessment. Arming the South, pp. 101-127. Available: DOI: 10.1057/9780230501256 (accessed: 10 July, 2017).

4. Broude, M., Deger, S. \& Somnath, Sen (2013). Defence, Innovation and Development: The Case of Israel. Journal of Innovation Economics \& Management, no 12, pp. 37-57.

5. Buck, D., K. Hartley \& Hooper N. (1993). Defence Research and Development, Crowding Out and the Peace Dividend. Defence and Peace Economics, vol. 4, no 2, April, pp. 161-178.

6. Chakrabarti, Alok K. \& Anyanwu, C.L. (1993). Defense R\&D, Technology, and Economic Performance: A Longitudinal Analysis of the US Experience. IEEE Transactions on Engineering Management, no 40, pp. 136-145.

7. Peled, D. (2001). Defense R\&D and Economic Growth in Israel: A Research Agenda. Haifa: Samuel Neaman Institute for Advanced Studies in Science and technology, p. 18. Available: DOI: 10.1111/j.1467-9779.2012.01550.x (accessed: 10 July, 2017).

8. Lin, E.S., Hamid, E. Ali \& Yu-Lung, Lu (2015). Does Military Spending Crowd Out Social Welfare Expenditures? Evidence from a Panel of OECD Countries. Defence and Peace Economics, vol. 26, no 1, pp. 33-48. Available: DOI: 10.1080/10242694.2013.848576 (accessed: 10 July, 2017).

9. Poole, E. \& Bernard J.-Th. (1992). Defence Innovation Stock and Total Factor Productivity. The Canadian Journal of Economics / Revue Canadienne d'Economique, vol. 25, no 2, pp. 438-452.

10. Frederiksen, P.C. \& Looney, R.E. (1985). Defense Expenditures and Economic Growth in Developing Countries: A Reply. Armed Forces and Society, no 11, pp. 298-301.

11. Guellec, D. \& B. Pottelsberghe de la Potterie (2001). R\&D Productivity Growth: Panel Data Analysis of 16 OECD Countries. OECD Economic Studies, no 33, pp. 113-114.

12. Hartley, K. (2006). Defence R\&D: Data issues. Defence and Peace Economics, no 17, pp. 169-175.

13. Hüseyin Bağcı \& Çağlar Kurç (2016). Turkey's Strategic Choice: Buy or Make Weapons? Defence Studies. Available: DOI: 10.1080/14702436.2016.1262742 (accessed: 10 July, 2017). 
14. Kuah, A.W. J. \& Loo, B.F.W. (2004). Examining the Defence Industrialization - Economic Growth Relationship: the Case of Singapore. RSIS Working Paper, no 70. Singapore: Nanyang Technological University.

15. Lavrinov, G.A. (2007). O vliyanii voyennykh raskhodov na razvitie ekonomiki strany. [On the Impact of Military Expenditures on the Country's Economic Development]. Voyennaya mysl', no 12, pp. 19-25 (in Russian).

16. Looney, R.E. (1989). The Influence of Arms Imports on Third World Debt. Journal of Developing Areas, no 23 (2), pp. 221-232.

17. Morales-Ramos, E. (2002). Defence R\&D Expenditure: the Crowding-Out Hypothesis. Defence and Peace Economics, vol. 13, no 5, January, pp. 365-383.

18. Moretti, E., Steinwender, C. \& Van Reenen, J. (2016). The Intellectual Spoils of War: Defense R\&D, Productivity and Spillovers. University of California at Berkeley.

19. Naughton, J. (2016). The Evolution of the Internet: From Military Experiment to General Purpose Technology. Journal of Cyber Policy, vol. 1, no 1, pp. 5-28. Available: DOI: 10.1080/23738871.2016.1157619 (accessed: 10 July, 2017).

20. Pieroni, L. (2009). Military Expenditure and Economic Growth. Defence and Peace Economics, no 20 (4), pp. 327-339.

21. Schein, A. (2017). The Economic Consequences of Wars in the Land of Israel in the Last Hundred Years, 1914-2014. Israel Affairs. Available: DOI: 10.1080/13537121.2017.1333731 (accessed: 10 July, 2017).

22. Schmid, J. (2017). The Diffusion of Military Technology. Defence and Peace Economics. Available: DOI: 10.1080/10242694.2017.1292203 (accessed: 10 July, 2017).

23. Solow, R.M. (1956). A Contribution to the Theory of Economic Growth. The Quarterly Journal of Economics. February, vol. 70, no 1, pp. 65-94.

24. Solow, R.M. (1957). Technical Change and the Aggregate Production Function. The Review of Economics and Statistics, vol. 39, no 3, pp. 312-320.

25. Uk Heo, Min Ye. (2016). Defense Spending and Economic Growth around the Globe: The Direct and Indirect Link. International Interactions. Available: DOI:10.1080/030 50629.2016.1149067 (accessed: 10 July, 2017).

26. Weitz, R. (2013). South Korea’s Defense Industry: Increasing Domestic Capabilities and Global Opportunities. Korea Economic Institute of America (Academic Paper Series), pp. 1-12.

27. Leonard, W.N. (1971). Research and Development in Industrial Growth. Journal of Political Economy, vol. 79, no 2, pp. 232-256. Available: DOI: 10.1086/259741 (accessed: 10 July, 2017).

28. Yakovlev, P. (2007). Arms Trade, Military Spending, and Economic Growth. Defence and Peace Economics, no 18, vol. 4, pp. 317-38. 